\title{
Causality and intentionality in the explanations of diachronic linguistics
}

The heading of the invitation to take part in the present discussion, Causal and final explanations in linguistics, has been changed above. I have used intentionality instead of the original final. In Spanish, and in corresponding words in some other languages, final and finalidad have meanings referring to "purpose" but in English final and finality have meanings referring to "end". Therefore I find it odd to use these words in any other way in English. On the other hand, English philosophers can use finality referring to "purpose". So it is not impossible for linguists also to do it.

Another problem with the original heading is that "linguistics" generally includes both synchronic and diachronic linguistics but the topic for our discussion is probably not meant to include synchronic problems. I have therefore included "diachronic" in the heading since this seems to be the topic for our discussion.

In the invitation to take part in the discussion it is mentioned that linguistics may "finally" be able "to provide explanations" and be able to apply "standards" which are "generally accepted in sciences". These are astounding statements. They imply that causal explanations can, and even should, be used in linguistics. This idea was long ago given up by good linguists. Few things have dragged down the standard of linguistics like the ideas that more or less causal explanations can be found in historical linguistics and that synchronic description is inferior because it has no explanations. No other author has shown as convincingly as Coseriu in Sincronía, Diacronía e Historia (1958) that changes in language do not occur by necessity, i.e. they have no cause, but they occur in the world of free will. The changes are intended, not caused. I immediately wrote an appreciative review of S.D.H. when I received it from Coseriu (see 1959 and the reprint with comments in 1988: 135-138).

The ideas of causality and explanation are unfortunately important in many linguistic orientations:

(1) Descriptions of modern language facts by general linguists sometimes contain unnecessary diachronic references. It happens that even linguists refer to older forms, perhaps even from Latin or ancient Greek, when they discuss the best form of a present-day word (for an example see 1982: 62). Also the meaning of a present-day word is sometimes thought to be explained by referring to its etymology. It is not uncommon that people who are not linguists want to know what some difficult word "really" means and are satisfied if they receive an historical explanation. It is undoubtedly thought that this somehow provides a deeper and better understanding. It is strangely enough also sometimes used by language experts in various languages who in daily newspapers explain the meanings of words to the readers.

(2) While the historical linguists, the later ones called neogrammarians, had to their credit great discoveries of the developments and relationships of European languages, their causal explanations were less admirable. It was common that the "physiological" description of a change was considered as a cause. For instance, one did not say that an old Germanic /hu:s/ diphthongised so as to become English or German /haus/ but one said that the change had occurred because of, by or through diphthongisation (see 1966: 85). Changes of sounds happened according to sound laws, a term influenced by the laws of the natural sciences. I 
have discussed these and related problems in 1966 (p. 75-76) and in $2012 \mathrm{~b}$ (p. 5-12). This thought complex containing an earlier and a later form and more or less clearly causal explanations dominated the teaching and research in many European language departments as late as the 1970 s.

(3) Some philologists describing an old text added historical explanations that had nothing to do with the text.

(4) In the neogrammarian era dialectologists did not present a systematic description of the sounds of a dialect and they sometimes used the sounds of an older era for the organisation of the modern sounds. This did not help a good description of the sounds of the modern dialect but rather prevented it.

(5) The early generativists describe facts of language by first positing fantasies called deep structures and then transforming them through rules into the present-day forms from which they had started. This nonsensical procedure also contains earlier and later forms although they are not from different times but part of a synchronic description. Generativists said that they possessed explanatory adequacy.

In summary, the task of the historical linguists (2) was to draw conclusions after having necessarily considered facts from different times. However, when linguists from the other four orientations $(1,3,4,5)$ involve earlier and later forms in their explanations, their procedure is meaningless. This has had two negative effects. On the one hand, they wasted time, ink and paper on spurious problems. On the other hand, their procedure hindered a deeper and more systematic study of their problems.

It should be noted that the word explanation has several meanings (see 2012b: 20). If it has the meaning "clarification" or similar, it does not involve a cause or a reason and it is not the word discussed in our context. One can assume that most of the early historical linguists and philologists who believed that they possessed explanations with causes had no clear idea about the nature of these explanations. They did not see clearly that if there is a cause, the effect, which occurs according to established laws, must follow. This means that predictions can be made. All this does not fit if one wants to describe change in language. What is usually considered to be a cause had existed for a long time without having had any effect. It cannot be explained why the effect occurs at one time and not at another nor why one effect rather than another one occurred.

From the 1930s there were many often heated discussions between historical linguists and usually younger linguists who argued that a synchronic description was possible and desirable while the historical linguists argued that to be scientific one needed (causal) explanations. While these discussions were most often oral, I took part in written discussions in addition to many oral ones (for references, see 2012a: 58-59 and 2012b: 8-12).

More recently linguists who were more systematic than the early historical linguists, still defend causality. A. Martinet argues correctly like other diachronic phonologists in his well known Économie des changements phonétiques (1956) that sound changes should when possible be seen as changes of sound systems and not as isolated changes one sound after another. In the systems one can observe interesting aspects such as what Martinet calls chain reaction, pressure in the system or gap in the system. However, when Martinet believes that such aspects contain causes for the changes, he is mistaken. My main counterargument is that aspects which by the speakers have been used without inconvenience for hundreds or even 
thousands of years cannot at some unexplained date turn out to be causes. Another counterargument is that generally more than one change, or no change at all, is imaginable. So why did one change rather than another one occur?

Some linguists believe that an invisible hand has been at work. This idea is, however, not acceptable because changes are entirely intentional and the result of the invisible hand is unintended.

Linguists and others are understandably impressed by the achievements of researchers in natural sciences, medicine and technologies but it is less understandable that so many linguists have not understood that the thinking of the others, in particular notions such as cause, effect and law, are not applicable to problems in humanities because the objects to be studied are different. (I have attempted to describe the differences between natural sciences and humanities in my 1978.)

In $2012 \mathrm{~b}$ I suggest that the main points in language change are as follows. A speaker gets the idea to use a new expression because he thinks it sounds good or even funny or such like. Change has an element of something attractive and it is intentional. I have suggested that one can use variatio delectat as a term for this aspect. The innovator lives in the world of free will and is not forced to use the new expression like water is forced to boil if one heats it to 100 degrees. A new expression most often disappears but it can happen that more and more speakers like it and start using it. It spreads and becomes first a sociolectal and a dialectal feature. It may also be so successful that it becomes a glottolectal feature. Innovations have features that already exist in the language. This is particularly easy to see in the changes in morphology called analogical. I have called a feature that is at the base of the change a prompt (see 2012b: 25). Such features have often been considered as causes. However, as pointed out above, one change as well as another, or no change at all, could have occurred. ${ }^{1}$ This means that a cause is not at work. Instead the innovating speaker had an intention although it is not possible to describe it exactly. However, if it had been possible to know everything that occurs in the speaker's mind, one would be able to see speech and its changes as caused.

Unlike what has often been thought, changes are usually not from a not well functioning form to a better functioning form because it is not believable that a form that has been used for hundreds or thousands of years did not function sufficiently well. So the changes are usually from a well functioning form to another well functioning form.

The problem of new things needing a new word can be seen as having at least an element of a causal explanation. If for example Italian immigrants introduce pizza to an English speaking country, the Italian word pizza is naturally also introduced. However, the Italian word has not caused the English word. As a matter of fact the word pizza pie was used earlier in Australia. And it is possible to imagine other words that could also have been chosen. A cause does not allow a choice. Both words mentioned are, however, undoubtedly strongly prompted.

1 Die meisten Veränderungen sind in dem Sinne arbiträr, dass ein gewisses Merkmal sich ebenso gut in der einen wie in der anderen Weise hätte verändern können. Gründe, warum das eine und nicht das andere eingetreten ist, sind im Allgemeinen nicht zu finden (see 1966: 89). 
I have taken it for granted that our discussion should only concern explanations in spoken language and not include written language (which I have dealt with in 2012b: 55-58). Two further possibilities certainly not either meant to be included are spoken language influenced by written language and written language influenced by spoken language (see 2012b: 58-65).

\section{References}

All by Göran Hammarström.

— (1959): Review of E. Coseriu, Sincronía, Diacronía e Historia, in: Le Maître Phonétique 112, 58-65.

- (1966): Linguistische Einheiten im Rahmen der modernen Sprachwissenschaft. Berlin: Springer Verlag.

- (1978): “Is linguistics a natural science?", in: Lingua 45, 15-31.

- (1982): "Diachrony in synchrony", in: J.P. Maher et al. (eds): Papers from the 3rd International Conference of Historical Linguistics. Amsterdam: John Benjamins B. V., $51-64$.

- (1988): "Synchrony, diachrony and communicative aspects", in: J. Albrecht et al. (eds): Energeia und Ergon II. Tübingen: Gunter Narr Verlag, 135-141.

- (2008): Fundamentals of synchronic linguistics. München: Lincom Europa.

- (2012a): Memories of a linguist 1940-2010. München: Lincom Europa.

- (2012b): Fundamentals of diachronic linguistics. München: Lincom Europa 